Original Research Article

\title{
Anti-inflammatory activity of 2-((3-(chloromethyl)benzoyl)oxy)benzoic acid in LPS-induced rat model
}

\author{
Yudy Tjahjono a, 1 , Srikanth Karnati $^{\mathrm{b}}$, Kuncoro Foe ${ }^{\mathrm{a}}$, Efendi Anggara a ${ }^{\text {, Yongky Novandi Gunawan a }}$, \\ Hendy Wijaya $^{a}$, Steven ${ }^{c}$, Handi Suyono ${ }^{c}$, Senny Yesery Esara, Wuryanto Hadinugroho ${ }^{a}$, \\ Hevi Wihadmadyatami ${ }^{\mathrm{d}}$, Süleyman Ergün ${ }^{\mathrm{b}}$, Ratna Megawati Widharna ${ }^{\mathrm{a}}$, Caroline ${ }^{\mathrm{a}, 1, *}$ \\ a Faculty of Pharmacy, Widya Mandala Ca tholic University Surabaya, Jalan Kalisari Selatan 1, Surabaya, 60237, East Java, Indonesia \\ ${ }^{\mathrm{b}}$ Institute of Anatomy and Cell Biology, Julus-Maximilians-University Würzburg, Würzburg, Germany \\ ${ }^{c}$ Fa culty of Medicine, Widya Mandala Ca tholic University Surabaya, Jalan Kalisari Selatan 1, Surabaya, 60237, East Java, Indo nesia \\ ${ }^{\mathrm{d}}$ Fa culty of Veterinary Medicine, Universitas Gadjah Mada, Jalan Fa una 2, Sleman, 55281, Yogyakarta, Indonesia
}

\section{A R T I C L E I N F O}

\section{Keywords:}

Anti-inflam ma tory activity

2-((3-(Chlor om ethyl)benzoyl)oxy)benzoic

acid

$\operatorname{COX}$

LPS

Rat

\begin{abstract}
A B S T R A C T
Introduction: Salicylic acid derivate is very popular for its activity to suppress pain, fever, and inflammation. One of its derivatives is acetylsalicylic acid (ASA) which has been reported repeatedly that, as a nonsteroidal anti-inflammatory drug (NSAID), it has a cardioprotective effect. Although ASA has various advantages, several studies have reported that it may induce severe peptic ulcer disease. We recently synthesized a new compound derived from salicylic acid, namely 2-((3-(chloromethyl)benzoyl)oxy)benzoic acid (3$\mathrm{CH}_{2} \mathrm{Cl}$ ) which still has the benefit of acetylsalicylic acid as an analgesic and antiplatelet, but lacks its harmful side effects (Caroline et al., 2019). In addition, in silico studies of 3- $\mathrm{CH}_{2} \mathrm{Cl}$ showed a higher affinity towards protein receptor cyclooxygenase-2 (COX-2; PDB: 5F1A) than ASA. We hypothesized that 3- $\mathrm{CH}_{2} \mathrm{Cl}$ inhibits the COX-2 activity which could presumably decrease the inflammatory responses. However, no knowledge is available on the anti-inflammatory response and molecular signaling of this new compound. Hence, in this study, we investigated the potential functional relevance of $3-\mathrm{CH}_{2} \mathrm{Cl}$ in regulating the inflammatory response in lipopolysaccharide (LPS)-induced rats. The results of this study show that this compound could significantly reduce the inflammatory parameter in LPS-induced rats.

Material and methods: Rats were induced with LPS of $0.5 \mathrm{mg} / \mathrm{kg}$ bw intravenously, prior oral administration with vehicle ( $3 \%$ Pulvis Gummi Arabicum / PGA), $500 \mathrm{mg} / 60 \mathrm{~kg}$ body weight (bw; rat dosage converted to human) of $3-\mathrm{CH}_{2} \mathrm{Cl}$ and ASA. The inflammatory parameters such as changes in the temperature of septic shock, cardiac blood plasma concentrations of IL-1 $\beta$ and TNF- $\alpha$ (ELISA), blood inflammation parameters, white blood cell concentrations, and lung histopathology were observed. Meanwhile, the stability of $3-\mathrm{CH}_{2} \mathrm{Cl}$ powder was evaluated.

Result: After the administration of $500 \mathrm{mg} / 60 \mathrm{~kg}$ bw of $3-\mathrm{CH}_{2} \mathrm{Cl}$ (rat dosage converted to human) to LPSinduced rats, we observed a significant reduction of both TNF- $\alpha\left(5.70+/-1.04 \times 10^{3} \mathrm{pg} / \mathrm{mL}, \mathrm{p}=<0.001\right)$ and IL-1 $\beta\left(2.32+/-0.28 \times 10^{3} \mathrm{pg} / \mathrm{mL}, \mathrm{p}=<0.001\right)$ cardiac blood plasma concentrations. Besides, we found a reduction of white blood cell concentration and the severity of lung injury in the $3-\mathrm{CH}_{2} \mathrm{Cl}$ group compared to the LPS-induced rat group. Additionally, this compound maintained the rat body temperature within normal limits during inflammation, preventing the rats to undergo septic shock, characterized by hypothermic $\left(\mathrm{t}=120 \mathrm{~min}\right.$.) or hyperthermic $(\mathrm{t}=360 \mathrm{~min})$ conditions. Furthermore, $3-\mathrm{CH}_{2} \mathrm{Cl}$ was found to be stable until 3 years at $25^{\circ} \mathrm{C}$ with a relative humidity of $75 \pm 5 \%$.

Conclusion: $3-\mathrm{CH}_{2} \mathrm{Cl}$ compound inhibited inflammation in the LPS-induced inflammation response model in rats, hypothetically through binding to COX-2, and presumably inhibited LPS-induced NF- $\beta$ signaling pathways. This study could be used as a preliminary hint to investigate the target molecular pathways of 3$\mathrm{CH}_{2} \mathrm{Cl}$ as a novel and less toxic therapeutical agent in alleviating the COX-related inflammatory diseases, and most importantly to support the planning and development of clinical trial.
\end{abstract}

\footnotetext{
* Correspond ing author.

E-mail address: caroline@ukwms.ac.id.

1 Authors contributed equally.
} 


\section{Introduction}

Salicylic acid derivatives are widely known for their activity to suppress pain, fever, and inflammation. Acetylsalicylic acid (ASA) is one of those derivatives, which has been widely distributed commercially as a non-steroidal anti-inflammatory drug (NSAID) and thoroughly investigated [1]. In addition to the anti-inflammatory functions, it has been also reported to mediate anti-platelet function or cardioprotective properties [2], and improve bone regeneration particularly in osteoporotic conditions $[3,4]$. Furthermore, recent studies reported peroxisome proliferator-activated receptor alpha (PPAR $\alpha$ ) served as a specific ASA-receptor mediating neuroprotective effect [5]. Although, ASA has various advantages, however, several studies have reported its harmful impact on the gastrointestinal tract, ranging from mild upper gastrointestinal problems to severe peptic ulcer disease [6-8].

Our group recently synthesized a new compound derived from salicylic acid, namely 2-((3-(chloromethyl)benzoyl)oxy)benzoic acid (3$\mathrm{CH}_{2} \mathrm{Cl}$ ) that has the benefits of acetylsalicylic acid but lacks its harmful side effects [9]. The analgesic and anti-platelet activity of $3-\mathrm{CH}_{2} \mathrm{Cl}$ was administered in normal Wistar rats. The data indicated that $3-\mathrm{CH}_{2} \mathrm{Cl}$ has a longer elimination half-life $\left(\mathrm{t}_{12}=39.4 \pm 3.9 \mathrm{~min}\right)$ and higher $\mathrm{C}$ $\max (0.57 \pm 0.02 \mu \mathrm{g} / \mathrm{mL})$ compared to ASA. These pharmacokinetic parameters showed that $3-\mathrm{CH}_{2} \mathrm{Cl}$ is widely and deeply distributed in all body tissues, yielding a slower onset of action and longer elimination time compared to ASA [9]. Moreover, our studies on in vitro human platelet aggregation studies postulated the mechanism of antiplatelet activity of $3-\mathrm{CH}_{2} \mathrm{Cl}$, by inhibiting $\mathrm{COX}-1$. Furthermore, in silico studies demonstrated a better affinity of $3-\mathrm{CH}_{2} \mathrm{Cl}$ for the $\mathrm{COX} 2$ receptor (PDB: $5 \mathrm{~F} 1 \mathrm{~A})$ than ASA [9]. Indeed, the COX-2 protein is predominantly induced by the main sources of prostaglandins (PGs) during inflammation [8]. Many researchers investigated the specific COX-2 mediated inflammatory responses, by administering endotoxin lipopolysaccharide (LPS) in various organs and tissues [10-12].

Lipopolysaccharide (LPS) is the outer membrane component of Gram-negative bacteria as the main pathogenic stimulator for severe infections (sepsis and acute lung injury) by inducing local and systemic inflammatory responses. The administration of LPS in healthy mice can activate LPS/TLR4 signal, inducing NF- $\kappa \beta$ activation and the production of pro-inflammatory cytokines (IL-1 $\beta$ and TNF- $\alpha$ ) $[13,14]$. The observation of drug effects with animal models given LPS emphasizes changes in specific inflammatory parameters such as febrile septic shock and pulmonary edema $[15,16]$.

Despite the novelty of $3-\mathrm{CH}_{2} \mathrm{Cl}$, no data is available to explain the anti-inflammatory response, molecular signaling, and the stability study of this compound. Therefore as part of our continuous efforts to develop better anti-inflammatory agents and based on the above observations, in this study, we investigate the anti-inflammatory ability of $3-\mathrm{CH}_{2} \mathrm{Cl}$ by comparing the changes in LPS-induced specific inflammatory parameters, such as changes in temperature of septic shock, cardiac blood plasma IL- $1 \beta$ and TNF- $\alpha$ concentrations, blood inflammation, cell concentration, and lung histopathology. The data generated in this study could be used as a preliminary guideline to investiga te the target molecular pathways of $3-\mathrm{CH}_{2} \mathrm{Cl}$ as a therapeutical agent in alleviating the COX-related inflammatory diseases, and most importantly to support the planning and development of this compound as a new drug candidate in the clinical trial. Meanwhile, the stability of the material was evaluated to provide basic information for further material design. Finally, we confirmed the anti-inflammatory response of 3$\mathrm{CH}_{2} \mathrm{Cl}$ particularly by observing the significant reduction of cardiac blood plasma IL- $1 \beta$ and TNF- $\alpha$ concentrations as well as other supporting parameters in LPS-induced rats treated with $3-\mathrm{CH}_{2} \mathrm{Cl}$ compared with untreated LPS-induced rats and proposed the COX-2 and NF- $\kappa \beta$ signaling pathways for the next level of studies.

\section{Materials and methods}

\subsection{Chemical synthesis, characterization, and stability study}

2-((3-(Chloromethyl)benzoyl)oxy)benzoic acid was synthesized in our laboratory as previously reported [9]. To observe the changes in chemical properties, we used Infrared (IR) Spectra Perkin Elmer System 60825 ranged from 4000 to $400 \mathrm{~cm}^{-1}$ (Perkin Elmer, Devon, UK) and High-Performance Liquid Chromatography (HPLC) Agilent 1220 Infinity LC G4288C HPLC systems (Agilent Technologies, California, USA). Additionally, we used Rheodyne $7725100-\mu \mathrm{L}$ injector and Shimadzu Shim-pack VP-ODS $150 \times 4.6 \mathrm{~mm}$ (Shimadzu Corporation, Tokyo, Japan) as a stationary phase. Sample analysis was conducted isocratically using a mixture of methanol: phosphate buffer $\mathrm{pH} 4.0(1: 1, \mathrm{v} / \mathrm{v})$ as a mobile phase with a flow rate of $1.0 \mathrm{~mL} / \mathrm{min}$. The KBF 720 climatic chamber binder (Binder $\mathrm{GmbH}$, Tuttlingen, Germany) was used to store compounds at a constant condition.

\subsection{Stability study}

The stability study of $3 \mathrm{CH}_{2} \mathrm{Cl}$ was conducted at a constant temperature $\left(40^{\circ} \pm 2^{\circ} \mathrm{C}\right)$ and $75 \% \pm 5 \%$ relative humidity for six months, according to [17]. The compound was observed before and after six months of storage. Samples collected at 13 different time points were analyzed using HPLC to determine whether there are physicochemical changes observed during storage. The shelf-life of this compound was then determined using the previously reported validation method analysis [9], as \% recovery (resulted in weight / theoretical weight $\mathrm{x}$ $100 \%)$.

\subsection{Animal model}

The experimental animals used in this study were 112 male Rattus norvegicus rats (3-month old, 150-200 grams (Pusvetma, Surabaya, Indonesia). Animals were housed in a temperature-controlled $\left(21-25^{\circ} \mathrm{C}\right)$ room, with a 12 -h light/dark cycle and they were allowed to consume food and drink ad libitum for 7 days. This study was approved by the University of Gadjah Mada Committee on the Use and Care of Animals No. 00050/04/LPPT/XI/2019. Healthy rats were measured at body temperatures between $37.2-38.5^{\circ} \mathrm{C}$ [18] using a digital thermometer (Omron Healthcare, Singapore). In general, rats were divided into four groups, consisting of the vehicle/untreated control, LPS treated, LPS + ASA treated, and LPS $+3-\mathrm{CH}_{2} \mathrm{Cl}$ treated groups. For cytokine concentration experiments, the animal groups were divided into more than four groups, due to different ASA and $3-\mathrm{CH}_{2} \mathrm{Cl}$ dosage applied (see below).

\subsection{Lipopolysaccharide (LPS) treatment}

Lyophilized powder of Lipopolysaccharide (LPS) isolated from Gram-negative of Escherichia coli type O111:B4 was diluted, yielding $0.5 \mathrm{mg} / \mathrm{ml}$ stock solution in $15 \mathrm{mM} \mathrm{NaCl}$ according to manufacturer's instruction (Sigma Aldrich, Saint Louis, USA). A single dose of LPS stock solution $(0.5 \mathrm{mg} / \mathrm{kg}$ bw) was injected intravenously through the tail vein for $30 \mathrm{~min}$, subsequently followed by drug administration orally.

\subsection{Acetylsalicylic acid (ASA) and 2-((3-(chloromethyl)benzoyl)oxy) benzoic acid $\left(3-\mathrm{CH}_{2} \mathrm{Cl}\right)$ dosage administration}

Pure acetylsalicylic acid (Labtech Citra Persada, Surabaya, Indonesia) was diluted by $3 \%$ Pulvis Gummi Arabicum (PGA) (Pharmalab, Bandung, Indonesia) suspension. $3-\mathrm{CH}_{2} \mathrm{Cl}$ was synthesized as previously described [9], and diluted by $3 \%$ PGA suspension. Following the injection of LPS, each dose of diluted ASA (LPS + ASA) and $3-\mathrm{CH}_{2} \mathrm{Cl}$ 
(LPS $+3-\mathrm{CH}_{2} \mathrm{Cl}$ ) compounds was orally administered to the animals. The cytokine concentration assay wa s then performed (see below). The doses administered to rats were 10.33 ; $51.65 ; 93.00 ; 134.33$; and $175.67 \mathrm{mg} / \mathrm{kg}$ body weight. The drug dosages were calculated according to the previous conversion method [19], representing 100; 500; 900; 1300 ; and $1700 \mathrm{mg} / 60 \mathrm{~kg}$ bw as the usual dose of drug treatment in human, respectively. Each experimental group consisted of six animals $(n=6)$ according to Federer's minimum required number of experimental designs [20] with a minor addition.

In another experimental setup, the white blood cells (WBC) cell blood count, temperature, and histological examinations were performed following the administration of ASA and $3-\mathrm{CH}_{2} \mathrm{Cl}$ at a single dose of $10.33 \mathrm{mg} / 200 \mathrm{~g}$ bw (equivalent to $500 \mathrm{mg} / 60 \mathrm{~kg} \mathrm{bw}$ ) to a predetermined group of rats that had been treated by LPS. The ASA and 3$\mathrm{CH}_{2} \mathrm{Cl}$ were administered orally at the first hour and the sixth hour after LPS injection. The control group (untreated rats) was injected with $15 \mathrm{mM} \mathrm{NaCl}$ (PT Widarta Bakti, Surabaya, Indonesia) intravenously and subsequently followed by the oral administration of $2 \mathrm{ml}$ of $3 \%$ PGA. In this experiment, each group consisted of ten animals $(n=10)$, following Federer's minimum required number of experimental designs [20].

\subsection{Blood preparation for WBC count and cytokine TNF- $\alpha$ and IL-1 $\beta$ concentrations assay}

Plasma for cytokine testing wa s obtained from the blood via intracardiac and collected on microtubes containing EDTA (500 mM). The microtube was centrifuged for $15 \mathrm{~min}$ at $1000 \mathrm{rpm}$. The supernatant containing blood plasma was collected in a tube and stored at $-4{ }^{\circ} \mathrm{C}$, for further cytokine testing.

In another experimental group, rat blood wa s collected (according to the previous method), $24 \mathrm{~h}$ after the oral administration of ASA, 3$\mathrm{CH}_{2} \mathrm{Cl}$, or control. A small amount of pure blood was taken to determine the concentrations of leukocytes, monocytes, granulocytes, and lymphocytes (Automatic Hematology Analyzer Horiba, USA). This analysis focused on the number of WBC cells in rats by administering LPS with ASA/3- $\mathrm{CH}_{2} \mathrm{Cl}(10.33 \mathrm{mg} / 200 \mathrm{~g}$ bw $)$.

\subsection{Cytokine TNF- $\alpha$ and IL-1 $\beta$ concentrations assay}

TNF- $\alpha$ and IL- $1 \beta$ cy tokines were tested using the Enzyme-linked immunosorbent assay kit (ELISA, Elabscience, Wuhan, China). Rat blood plasma was diluted with $500 \mathrm{mM}$ EDTA $(1: 2, \mathrm{v} / \mathrm{v})$ and incubated in a coated ELISA 96-er tube. The extracellular TNF- $\alpha$ and IL-1 $\beta$ concentrations were analyzed by color change (Multiskan GO microplate spectrophotometer, Thermo Scientific, Vantaa, Finland). Cy tokine concentrations were determined using optical density (OD) regression and GraphPad Prism Software v.7 as a standard.

\subsection{Temperature measurement assay}

The rectal temperature of each animal in each group was measured periodically with a digital thermometer (Omron Healthcare, Singapore). The initial temperature (T0: $37.2-38.5{ }^{\circ} \mathrm{C}$ ) was the temperature of rats following adaptation for $30 \mathrm{~min}$ at $24-26{ }^{\circ} \mathrm{C}$ [18]. The observation of temperature changes was carried out every $60 \mathrm{~min}$ for $600 \mathrm{~min}$. The time point was symbolized as $\mathrm{T}_{\mathrm{n}}$. Whereas " $\mathrm{n}$ " stands for $60 \mathrm{~min}$ (T60), $120 \mathrm{~min}$ (T120), and with subsequent addition in $60 \mathrm{~min}$ intervals, until it reaches the maximal time point $600 \mathrm{~min}$ (T600). The temperature changes $(\triangle T)$ were calculated as changes in the body temperature of each animal at each measurement time interval against the initial temperature.

\subsection{Histopathology study}

The rats' lungs were dissected after drug administration, temperature measurements, and euthanasia. The lung organs were fixed with $10 \%$ formalin solution, dehydrated with alcohol-xylene, and immersed in paraffin before cutting the tissue. All tissue sections were stained with hematoxylin-eosin. Lung injury was observed microscopically at 10 randomly selected spots. The observation scores were determined according to the observation of pulmonary edema, as follows: normal $=0$; perivascular edema $=1$; peribronchial edema, interstitial edema, perivascular cell infiltration $=2$; alveolar edema, interstitial cell infiltration $=3$; and alveolar cell infiltration $=4$ [21].

\subsection{Statistical evaluation}

Statistical analysis was performed using post-hoc-dunnet test and $p$ values less than 0.05 were considered statistically significant. The data subsets were graphically presented using GraphPad Prism Software v.7. Unless others mentioned, all of the data related to $3-\mathrm{CH}_{2} \mathrm{Cl}$ animal groups were compared with the positive control (LPS + Vehicle groups).

\section{Results}

3.1. 3- $\mathrm{CH}_{2} \mathrm{Cl}$ exerts anti-inflammatory activity by a significant reduction of cardiac blood plasma cytokine TNF- $\alpha$ and IL-1 $\beta$ concentrations in LPS-treated rat model

To assess the degree of inflammation through humoral components, we observed the cardiac blood plasma cytokine concentration of LPSinduced rats, particularly pro-inflammatory TNF- $\alpha$ and IL-1 $\beta$ (Fig. 1).
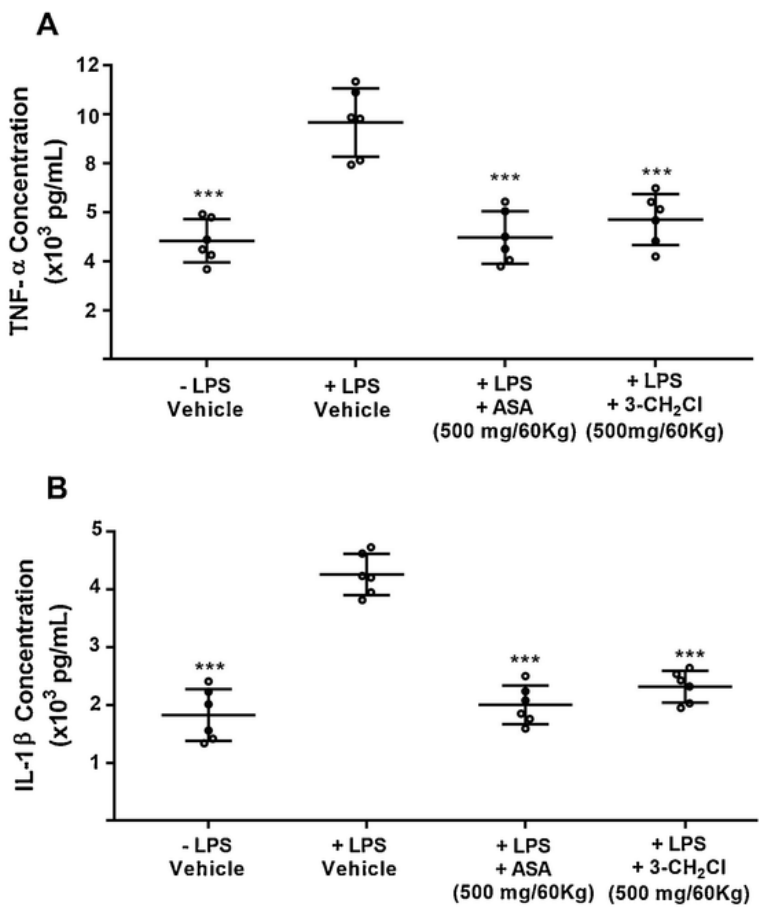

Fig. 1. Administration of 3-CH $2 \mathrm{Cl}$ lowered cytokine TNF- $\alpha$ and IL-1 $\beta$ concentrations in the LPS-treated rat model.

Effect of $500 \mathrm{mg} / 60 \mathrm{~kg}$ bw of $3-\mathrm{CH}_{2} \mathrm{Cl}$ as well as ASA on plasma TNF- $\alpha$ (A) and IL-1 $\beta$ (B) levels in LPS-induced rats $(n=6)$, showing a significant reduction of both cytokines concentration compared with the control group (+ LPS + vehicle). Blood samples were collected after LPS + ASA and LPS $+3-\mathrm{CH}_{2} \mathrm{Cl}$ administration as presented in the method section. Results were expressed as mean \pm standard deviation (SD), and statistical significance was shown as $* * * \mathrm{P}<0.001$. 
The TNF- $\alpha$ and IL-1 $\beta$ levels were significantly increased in LPS-treated rats, and decreased in LPS + ASA treated and $\mathrm{LPS}+3-\mathrm{CH}_{2} \mathrm{Cl}$ treated groups (see also supplementary Fig. 2). We observed significant reduction of both TNF- $\alpha$ and IL-1 $\beta$ cytokines, particularly following the treatment of LPS-induced rats with $500 \mathrm{mg} / 60 \mathrm{~kg}$ bw of ASA (TNF- $\alpha$ $4.97+/-1.07 \times 10^{3} \mathrm{pg} / \mathrm{mL}, \mathrm{p}=<0.001 ; \mathrm{IL}-1 \beta 2.01+/-0.33 \times 10^{3}$ $\mathrm{pg} / \mathrm{mL}, \mathrm{p}=<0.001)$ or $3-\mathrm{CH}_{2} \mathrm{Cl}\left(\mathrm{TNF}-\alpha 5.70+/-1.04 \times 10^{3} \mathrm{pg} / \mathrm{mL}\right.$, $\left.\mathrm{p}=<0.001) ; \mathrm{IL}-1 \beta 2.32+/-0.28 \times 10^{3} \mathrm{pg} / \mathrm{mL}, \mathrm{p}=<0.001\right)$. We found no dose-dependent decrement of TNF- $\alpha$ and IL-1 $\beta$ levels in the LPS $+3-\mathrm{CH}_{2} \mathrm{Cl}$ treated group. The cytokine level in LPS + ASA treated animal group decreased after treatment with $100 \mathrm{mg} / 60 \mathrm{~kg}$ bw and $500 \mathrm{mg} / 60 \mathrm{~kg}$ bw of ASA and increased again at other dosages greater than $500 \mathrm{mg} / 60 \mathrm{~kg}$ bw. The highest cytokine levels were observed in the LPS treated animal group and LPS + ASA treated animal group (1700 mg/60 kg bw of ASA). Although the concentration of cytokines in the LPS $+3-\mathrm{CH}_{2} \mathrm{Cl}$ treated group was positioned approximately at the same level, a subtle elevated cytokine level was observed in the 3$\mathrm{CH}_{2} \mathrm{Cl}$ treated animal group ( $1300 \mathrm{mg} / 60 \mathrm{~kg}$ bw of $\left.3-\mathrm{CH}_{2} \mathrm{Cl}\right)$. Taken together, we observed the significant reduction of cardiac blood plasma TNF- $\alpha$ and IL- $1 \beta$ in $3-\mathrm{CH}_{2} \mathrm{Cl}$ treated animal groups particularly following the treatment of LPS-induced rats with $500 \mathrm{mg} / 60 \mathrm{~kg} \mathrm{bw}$ compound dosage.

\section{2. $3-\mathrm{CH}_{2} \mathrm{Cl}$ exerts an anti-pyrogenic effect by reducing the rectal temperature of LPS-treated rat hyperthermic model}

To measure the anti-pyrogenic activity of the compounds in endotoxin LPS-treated animals, we observed the mean temperature difference $(\Delta \mathrm{T})$ for $10 \mathrm{~h}$ in the 60 -min interval, with T0 was defined as the starting point, when the animal was intravenously injected by a single dose of $0.5 \mathrm{mg} / \mathrm{kg}$ bw of LPS. As shown in Fig. 2, the rats displayed typical septic shock in response to a single dose of $0.5 \mathrm{mg} / \mathrm{kg}$ bw of LPS (+ LPS vehicle group), indicated by hypothermic condition (negative $\Delta \mathrm{T}$ ), particularly at $\mathrm{T} 60$ and $\mathrm{T} 120$. The rectal temperature difference began to rise 240-300 min after the LPS injection and reached its peak value at about $360 \mathrm{~min}$, interpreted as a hyperthermic condition. The rectal temperature remained elevated until the end of the observation. In the $\mathrm{LPS}+3-\mathrm{CH}_{2} \mathrm{Cl}$ group, the rectal temperature was relatively stable from $\mathrm{T} 0$ until the first $3-\mathrm{CH}_{2} \mathrm{Cl}$ oral administration at $\mathrm{T} 60 \mathrm{~min}$. No significant differences were observed in comparison with its basal normal temperature until T180. It began to rise slightly at 240-360 minutes observation point, and gradually decreased again following the second oral administration of $500 \mathrm{mg} / 60 \mathrm{~kg}$ bw of $3-\mathrm{CH}_{2} \mathrm{Cl}$ at T360, until reaching its basal temperature at T600. However, in LPS + ASA treated group, the animals showed no hypothermic response following LPS injection. It began to rise about $60 \mathrm{~min}$ after the first oral administration of $500 \mathrm{mg} / 60 \mathrm{~kg}$ bw of ASA. In contrast to the LPS treated group, the LPS + ASA group exhibited a slight hyperthermic condition with the maximum temperature difference $(\Delta \mathrm{T})$ reaching $+0,55 \pm 0,22{ }^{\circ} \mathrm{C}$. The temperature began to decrease gradually and fell rapidly after the second oral administration of ASA. It reached the basal normal temperature at T480 until the end of the observation. Taken together, animals treated with the $3-\mathrm{CH}_{2} \mathrm{Cl}$ group shows relatively stable temperature from T0 until T600. Now significant hypothermic and hyperthermic conditions were observed within the 3 $\mathrm{CH}_{2} \mathrm{Cl}$ treated group.

\section{3. $3-\mathrm{CH}_{2} \mathrm{Cl}$ suppresses the immune cells and therefore exerts anti- inflammatory properties by decreasing the cardiac white blood cell concentration in LPS-induced rats}

To investigate whether $3-\mathrm{CH}_{2} \mathrm{Cl}$ could suppress the immune cells in LPS-treated rats, we measured the number of absolute leukocytes (Fig. 3A), lymphocytes (Fig. 3B), monocytes (Fig. 3C), and granulocytes (Fig. 3D) in isolated whole blood. Twenty-four hours after LPS treatment with additional repeated doses (two times) of oral administration of the salicylic acid compound in between, the animals were euthanized and the blood cells were counted immediately. We observed a significant increase of all WBCs differential counts, with the highest WBCs concentration observed in all LPS-injected rat groups, followed by LPS + ASA and LPS $+3-\mathrm{CH}_{2} \mathrm{Cl}$ groups. The untreated rats showed the lowest WBCs concentration. In leukocytes and lymphocytes parameters, a very low blood cell concentration was observed. Additionally, the leukocytes and lymphocytes parameters observed in the LPS + 3$\mathrm{CH}_{2} \mathrm{Cl}$ group were slightly lower than those observed in the LPS + ASA group, suggesting the alleviated suppression of immune cells mediated by $3-\mathrm{CH}_{2} \mathrm{Cl}$ compared with ASA.

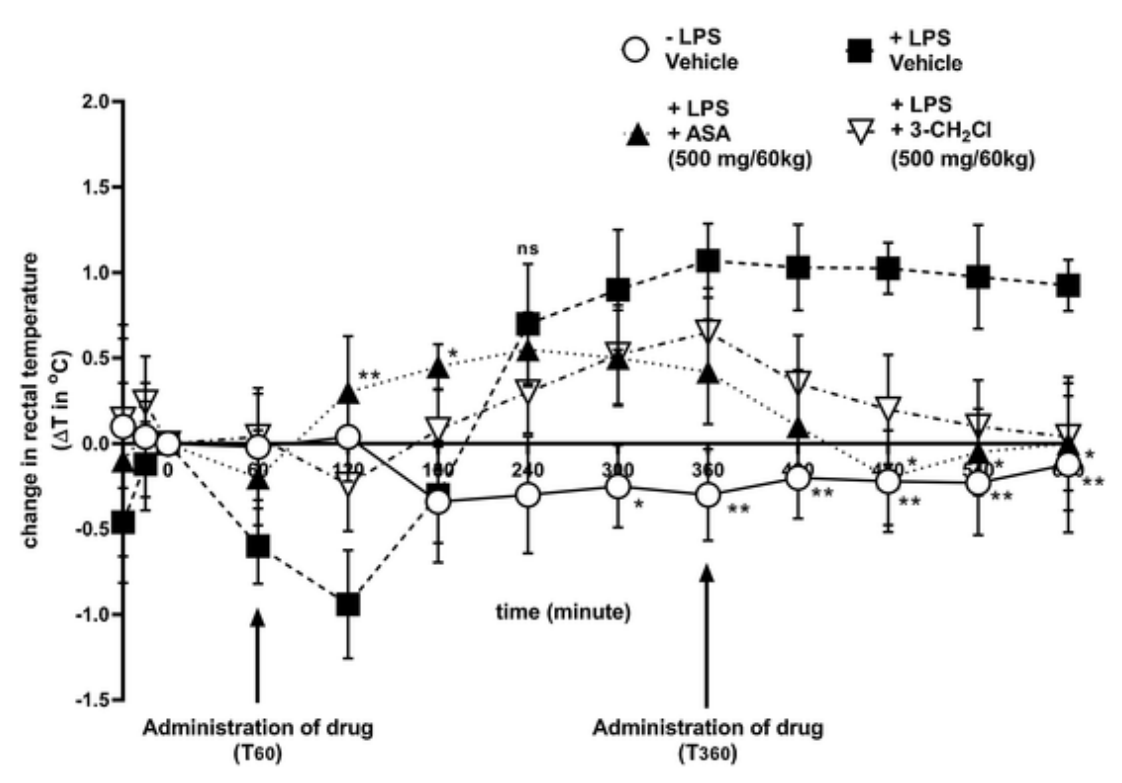

Fig. 2. Administration of $3-\mathrm{CH}_{2} \mathrm{Cl}$ reduced rectal temperature of LPS-treated rat hyperthermic model.

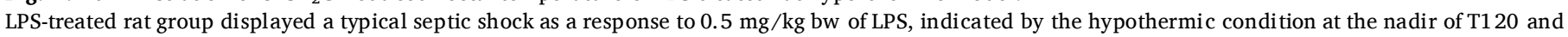

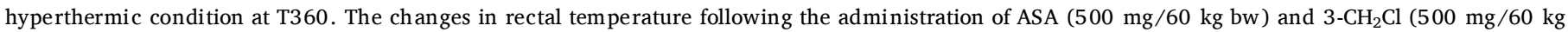

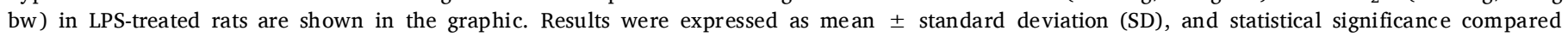
with + LPS/Vehicle was shown as *P $<0.05$ or $* * \mathrm{P}<0.01$. "Ns" or without asterisks indicated as non-significant. 

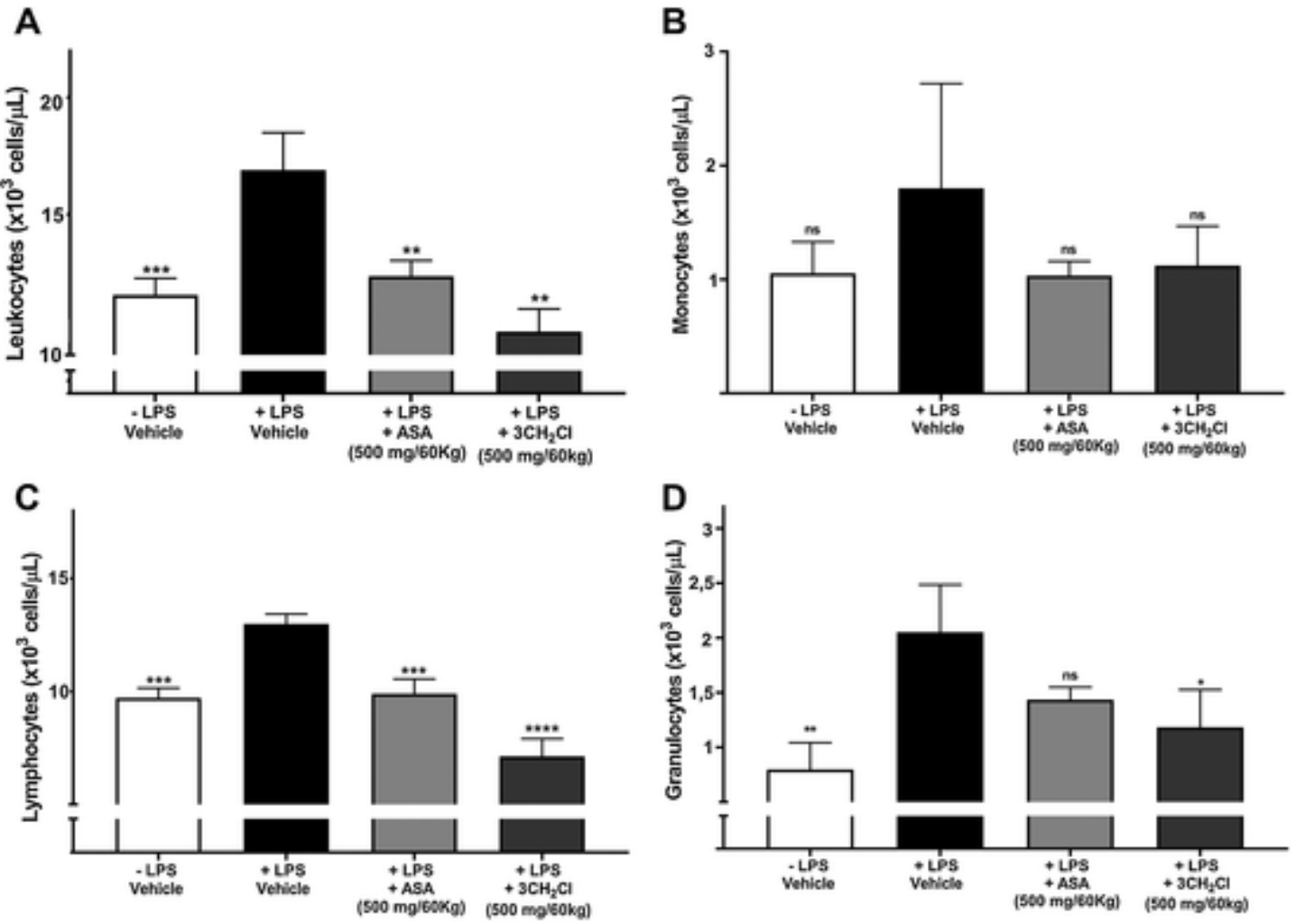

Fig. 3. Administration of 3- $\mathrm{CH}_{2} \mathrm{Cl}$ reduced differential white blood cells count in the LPS-treated rat model.

The number of leukocytes (A) as well as monocytes (B), lymphocytes (C), and granulocytes (D) increased in LPS-treated rats groups (n = 10) compared with the control group -LPS + vehicle. After administration of LPS + ASA $(500 \mathrm{mg} / 60 \mathrm{~kg} \mathrm{bw})$ and $3-\mathrm{CH}_{2} \mathrm{Cl}(500 \mathrm{mg} / 60 \mathrm{~kg}$ bw $)$, the blood cells count decreased and it was shown that $3-\mathrm{CH}_{2} \mathrm{Cl}$ had a good effect as ASA. Results were expressed as mean \pm standard deviation (SD), and statistical significance was shown as "ns" P > 0.05, *P $<0.05, * * \mathrm{P}<0.01, * * * \mathrm{P}<0.001$, or **** $\mathrm{P}<0.0001$

\subsection{Administration of 3- $\mathrm{CH}_{2} \mathrm{Cl}$ reduce LPS induced acute lung injury}

To analyze the direct impact of the salicylic acid-derived compound on lessening the typical acute lung injury $24 \mathrm{~h}$ after LPS administration, we performed the microscopic histological analysis with a scoring system. Representative histological sections from all experimental groups were presented in Fig. 4A-D. The normal untreated rat group (Fig. 4A) showed relatively clear alveolar spaces and indicated no infiltration of immune cells. In contrast, the lung of LPS-treated animal groups (Fig. 4B) exhibited intra-alveolar edema, massive cell infiltration, and hemorrhage. Following the administration of $500 \mathrm{mg} / 60 \mathrm{~kg}$ bw of ASA in the LPS-injected rat group (Fig. 4C), we observed a significant reduction of cell infiltrates and alveolar edema. Meanwhile, the administration of $500 \mathrm{mg} / 60 \mathrm{~kg}$ bw of $3-\mathrm{CH}_{2} \mathrm{Cl}$ (Fig. 4D) could reduce the degree of lung injury better than ASA, indicated visually by slightly bigger intra-alveolar space. To have a better analysis of the observation statistically, we converted the visual interpretation into the numeric score and presented the data in graphical lung injury scores (Fig. 4E). Indeed, the highest score indicating severely damaged lungs was significantly demonstrated in LPS treated animal groups $(3.125 \pm 0.39)$. On the other hand, a slight lung injury score was demonstrated in LPS + ASA and $3-\mathrm{CH}_{2} \mathrm{Cl}$ group summary.

\subsection{The $3-\mathrm{CH}_{2} \mathrm{Cl}$ powder is stable until 3 years at $25^{\circ} \mathrm{C}$ with a relative humidity of $75 \pm 5 \%$}

The Physico-CHemical characteristics of $3-\mathrm{CH}_{2} \mathrm{Cl}$ were white powder and odorless. Following storage at $40^{\circ} \pm 2^{\circ} \mathrm{C} / 75 \% \pm 5 \% \mathrm{RH}$ for 6 months, the recovery percentages of this compound at 13 different sampling points can be seen in Supplementary Table 1. This compound was found to be stable, as shown in the HPLC chromatogram and IR spectroscopy results (Fig. 5), by comparing the results before and after storage for 6 months (Fig. 5a). Besides, there was no additional peak attributed to salicylic acid in the HPLC chromatogram (Fig. 5b), indicating no chemical degradation observed until the end of the stability study. Through theoretical conversion according to ICH guidelines, the $3-\mathrm{CH}_{2} \mathrm{Cl}$ powder is stable until 3 years at $25^{\circ} \mathrm{C}$ with a relative humidity of $75 \pm 5 \%$.

\section{Discussion}

It has been previously reported that salicylic acid and its derivate ASA prevent inflammation in part by enzyme cyclooxygenase inhibition. Besides, salicylic acid and its derivate ASA could prevent inflammation by their specific inhibition of IKK- $\beta$, preventing the activation of NF-k $\beta$ and thereby significantly suppress genes involved in the pathogenesis of inflammatory response such as cytokines [22]. Although, ASA as an anti-inflammatory agent has various advantages, however, its harmful impact on the gastrointestinal tract motivated our research group to investigate the anti-inflammatory property of a novel and less toxic salicylic acid derived $3-\mathrm{CH}_{2} \mathrm{Cl}$ as another therapeutic drug in the LPS-induced rat model.

LPS-administration in rodents has been used frequently to study the inflammatory response, specific organ failure, and its typical physiological changes [23]. LPS could bind to its receptor in Toll-like receptor 4 (TLR4)-dependent pathway, and stimulate the cytokine through the Mitogen-activated protein kinase (MAPK) and nuclear factor kappa beta $(\mathrm{NF}-\kappa \beta)$ routes, which may activate several immunological responses [13], particularly cytokines transcription, and therefore may cause severe inner organ injury, such as typical LPS-generated acute lung injury (ALI). Although the application of LPS-induced inflammation response model in rats exerts various differences compared with 

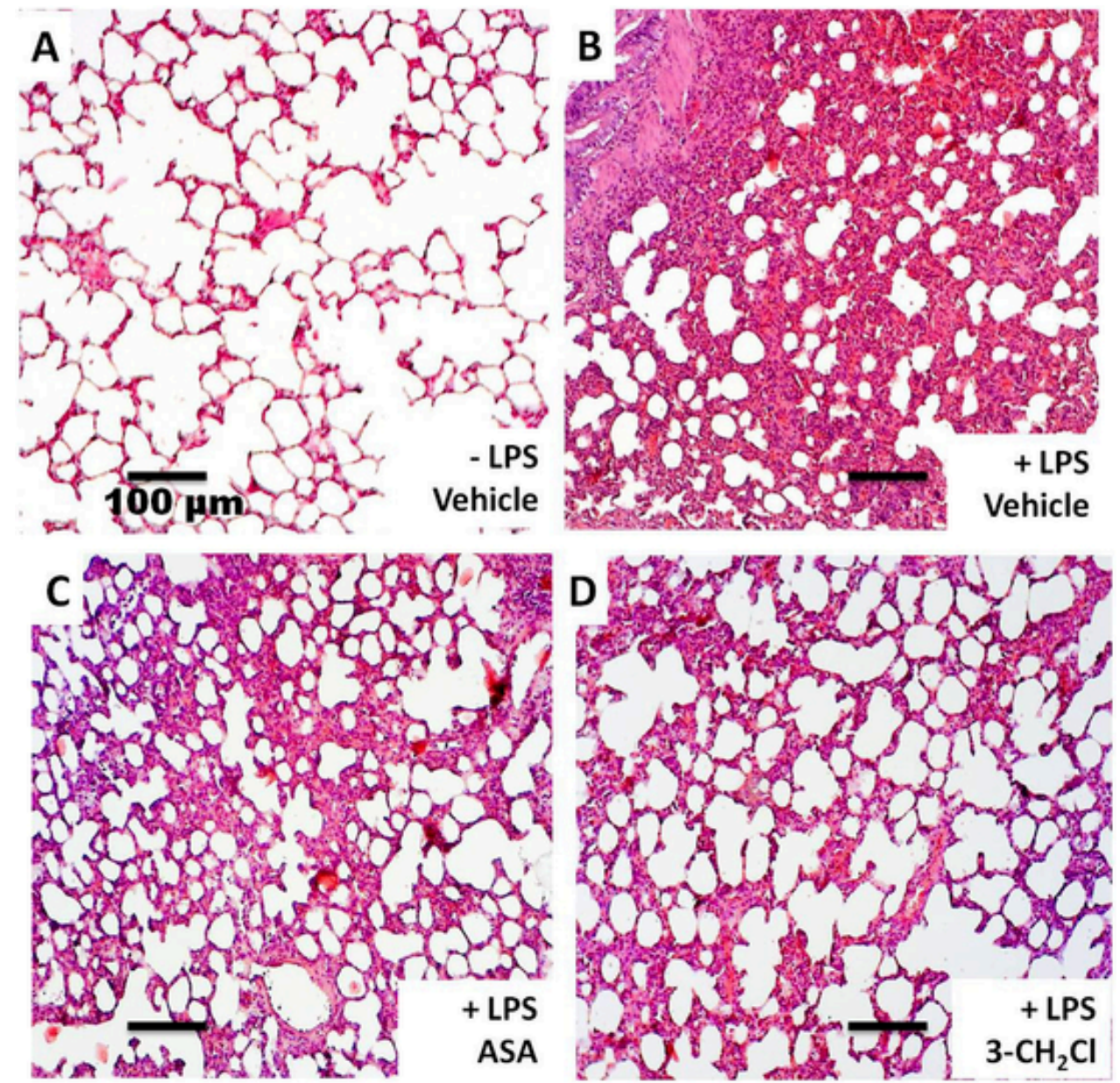

E.

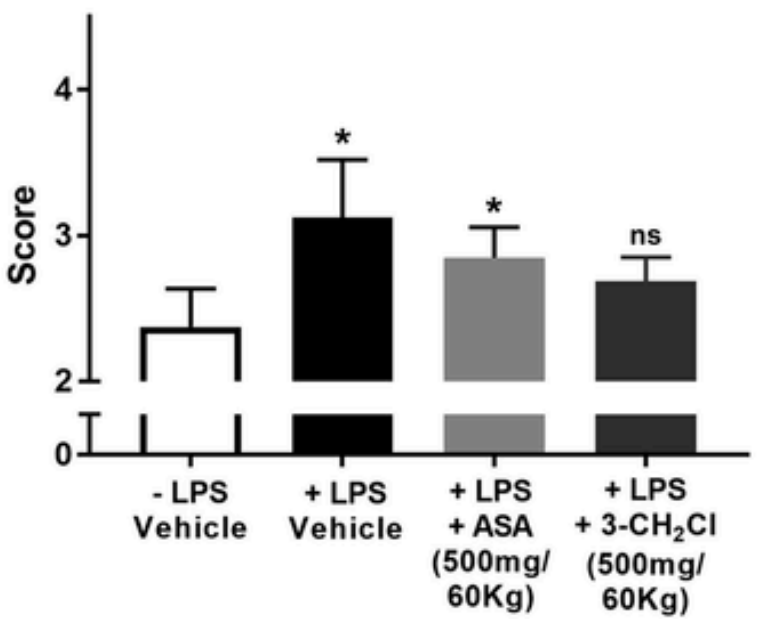

Fig. 4. Administration of 3- $\mathrm{CH}_{2} \mathrm{Cl}$ reduced lung edema in the LPS-treated rat model.

Representative histological sections from the experimental group $(n=10)$ showed acute lung injury, characterized by lung edema, intra-alveolar hemorrhage, and interstitial cell infiltration in the + LPS + vehicle group (B) compared with the control group -LPS + vehicle (A). The administration of the dose of $500 \mathrm{mg} / 60 \mathrm{~kg}$ bw of ASA (C) and particularly with $500 \mathrm{mg} / 60 \mathrm{~kg}$ bw of $3-\mathrm{CH}_{2} \mathrm{Cl}$ in intravenous LPS-injected rats exhibited lesser lung injury (D). Lung injury score was shown (E) as the mean \pm standard deviation (SD).

humans, there are several similarities which have been reported, in the inflammatory responses to LPS between rodents and human. Therefore this method is still reliable for preliminary investigation of the inflammation response [24], as carried out for the anti-inflammatory study of potential $3-\mathrm{CH}_{2} \mathrm{Cl}$ in the pre-clinical phase. In addition to our previously reported in silico docking results which showed that $3-\mathrm{CH}_{2} \mathrm{Cl}$ could act as a potential COX-2 ligand [9,25], the above-mentioned signal transduction led us towards another hypothesis of the $3-\mathrm{CH}_{2} \mathrm{Cl}$ mechanism of action, which might have the similar pathway with ASA.

The pro-inflammatory cytokines concentration plays a pivotal role, particularly in the investigation of the drug's effectiveness to inhibit LPS-induced inflammation. TNF- $\alpha$ and IL- $1 \beta$ are widely known as a 


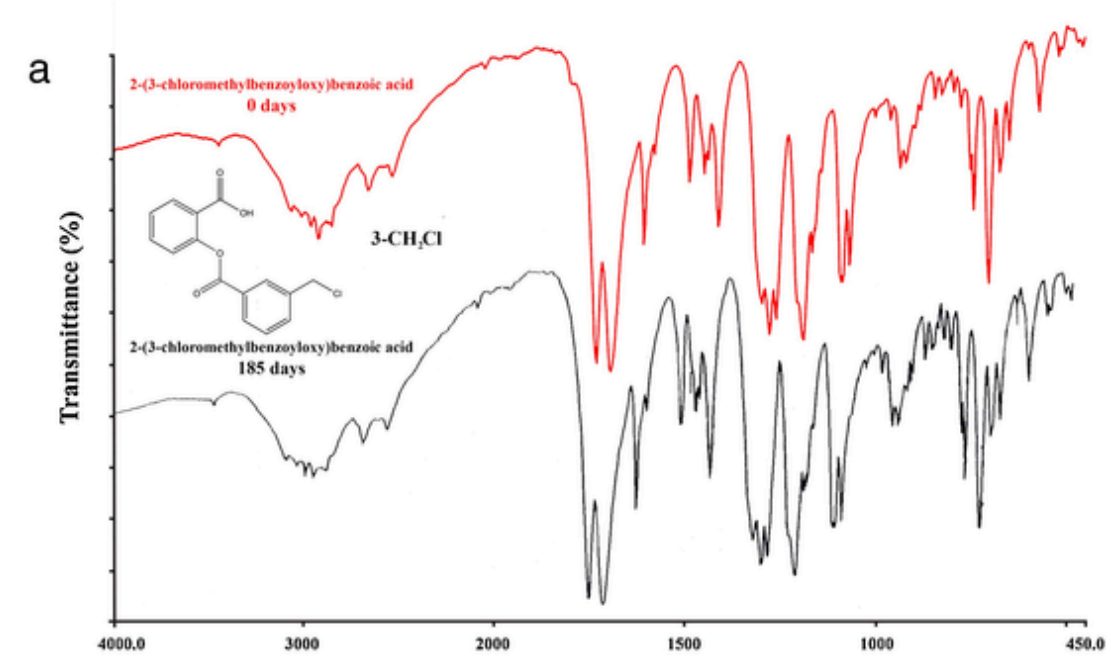

b

Wavelength $\left(\mathrm{cm}^{-1}\right)$

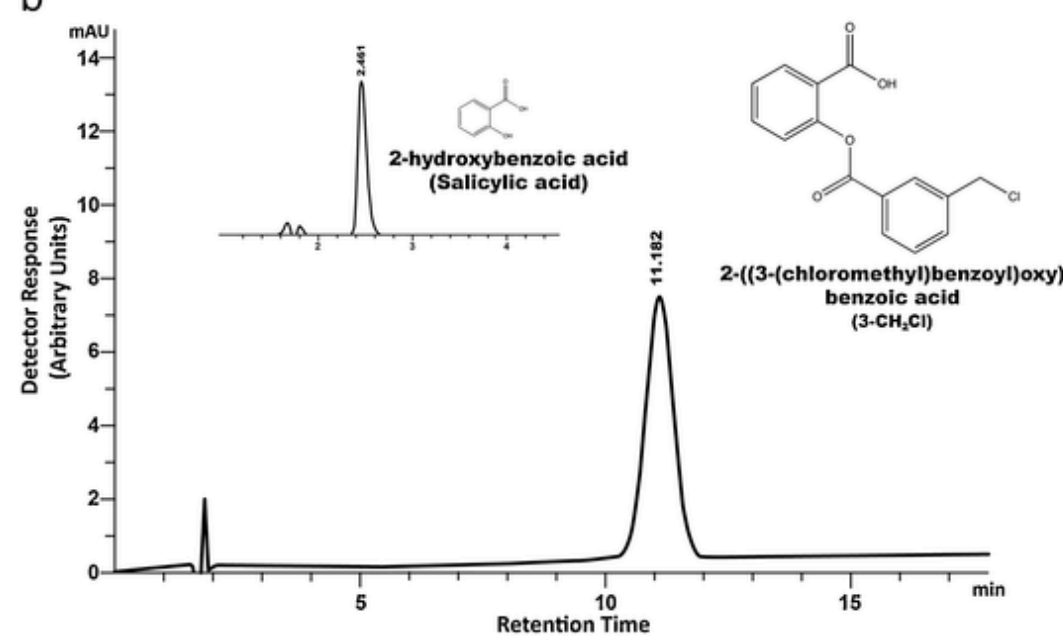

Fig. 5. A fingerprint of the $3-\mathrm{CH}_{2} \mathrm{Cl}$ compound.

(A) Patterns of 3- $\mathrm{CH}_{2} \mathrm{Cl}$ infrared spectroscopy on day-0 (red) and day-185 (black) showed an identical pattern. (B) HPLC pattern of a typical 3-CH ${ }_{2} \mathrm{Cl}$ compound. A small graphic indicates a salicylic acid pattern as a precursor compound. No impurities were detected.

representative of pro-inflammatory cytokines and have been widely used as a peripheral marker, particularly because of the association with its transcription factor, NF- $\kappa$. Indeed, our data in Fig. 1 did support this hypothesis by the specific reduction of rat TNF- $\alpha$ and IL-1 $\beta$ cardiac blood plasma concentrations following the oral administration of $500 \mathrm{mg} / 60 \mathrm{~kg}$ bw of $3-\mathrm{CH}_{2} \mathrm{Cl}$ in LPS-induced systemic inflammation rats. This may indicate that this compound might exert antiinflammatory molecular pathways properties through NF- $\kappa \beta$ signaling. To investigate the dose-dependent effect, we evaluated the cytokine concentration following the administration of salicylic acid derivate in five increment concentrations. Interestingly, we found the dosedependent decrement of both plasma cytokine TNF- $\alpha$ and IL- $1 \beta$ concentrations, ranging from $100-500 \mathrm{mg} / 60 \mathrm{~kg}$ bw with the nadir was reached by $500 \mathrm{mg} / 60 \mathrm{~kg}$ bw. The preliminary findings pointed towards the similar anti-inflammatory effect of $3-\mathrm{CH}_{2} \mathrm{Cl}$ compared with ASA, particularly at the dose of $500 \mathrm{mg} / 60 \mathrm{~kg}$ bw. Therefore to simplify the overall experimental design due to limited resources, we focused on the observation of other anti-inflammatory parameters following $500 \mathrm{mg} / 60 \mathrm{~kg}$ bw dosage administration only. Other physiological changes following the reduction of the pro-inflammatory cytokine, such as isothermic antipyretic effect, immune cell depletion, and the reduction of organ damage severity, are expected after $500 \mathrm{mg}$ / $60 \mathrm{~kg}$ bw dose of $3-\mathrm{CH}_{2} \mathrm{Cl}$ administration compared with vehicleadministered LPS-rats.
It is known that after LPS-administration, typical leukopenia is observed in the first 1-4 h examination, followed by a rebound leukocytosis in a zenith of $12-24 \mathrm{~h}$ after LPS injection. This is indicated as IL-6 stimulated neutrophilia to increase the survival of neutrophils during the acute inflammatory condition [26]. Therefore to reproduce a contrast result of $3-\mathrm{CH}_{2} \mathrm{Cl}$ action in white blood cell concentration of LPStreated animals group, we used the 24-h time point as our starting analysis. A significant increase in white blood cell concentration was observed in LPS-treated animals (Fig. 3), this is in ag reement with [27]. The administration of $500 \mathrm{mg} / 60 \mathrm{~kg}$ bw of $3-\mathrm{CH}_{2} \mathrm{Cl}$ in LPS-animals could reduce the white blood cell concentration. This phenomenon could also be seen in ASA treated animals group, indicating the antiinflammatory action of $3-\mathrm{CH}_{2} \mathrm{Cl}$ and ASA to inhibit neutrophilia, particularly $24 \mathrm{~h}$ post endotoxin LPS injection.

In terms of temperature changes, LPS generated fevers commonly polyphasic [28], and may vary depending on multiple methodological factors such as dose and laboratory ambient. During the initial phase of intravenous LPS injection, the animals show typical septic shock hypothermia and are subsequently followed by the hyperthermia phase [15]. Those typical polyphasic temperatures during systemic inflammation are triggered mainly by cyclooxygenase isoforms and maintained particularly in the brain [29]. As expected, our results in Fig. 2 support hypothetical arguments of $3-\mathrm{CH}_{2} \mathrm{Cl}$ potential inhibitory ligands namely COX-2. In comparison to LPS-treated rats, the dose administra- 
tion of $500 \mathrm{mg} / 60 \mathrm{~kg}$ bw of $3-\mathrm{CH}_{2} \mathrm{Cl}$ could stabilize the rat's body temperature, preventing them to undergo polyphasic hypothermic and hyperthermic conditions. The hyperthermic prevention of $3-\mathrm{CH}_{2} \mathrm{Cl}$ may indicate that this compound could have antipyretic properties. Following the administration of $3-\mathrm{CH}_{2} \mathrm{Cl}$, this compound may block the COX2 activity and thus inhibit hyperthermia during systemic inflammation.

As mentioned before, besides the polyphasic thermal character, intravenous LPS administration could induce severe acute lung injury (ALI) through histologically observed massive infiltration of the inflammatory cell causing pulmonary edema, which is triggered by the generation of reactive oxygen species (ROS), increased cytokine responses, MAPK activation, NF- $\kappa \beta$ expression, and its associated molecules [16]. As expected, severe ALI was demonstrated in the typical histological section of LPS-treated rat lungs (Fig. 4A), as well as its associated scoring data (Fig. 4B) $24 \mathrm{~h}$ post LPS injection. Additionally, we demonstrated that $3-\mathrm{CH}_{2} \mathrm{Cl}$ treatment could reduce partially the severity of ALI, better than ASA. Even though the effect of $3-\mathrm{CH}_{2} \mathrm{Cl}$ has not been well studied at the molecular level in the context of inflammatory cascades, these histological findings supported our general observational study, namely the anti-inflammatory of $3-\mathrm{CH}_{2} \mathrm{Cl}$ which may cause the inhibition of immunological signal during inflammation, as well as decrease the immune cell concentration and its cytokine response. For the next aim of studies, investigation of reactive oxygen species (ROS) production and cyclooxygenase inhibition in the presence of $3-\mathrm{CH}_{2} \mathrm{Cl}$ would strengthen the preclinical observation of this compound in inhibiting inflammation.

Meanwhile, to complete the previously reported physicochemical characterization of 3- $\mathrm{CH}_{2} \mathrm{Cl}$ [9], in this study we observed the stability of this compound based on storage time and humidity parameters. Our data as shown in Fig. 5A with additional HPLC pattern (Fig. 5B) indicated that $3-\mathrm{CH}_{2} \mathrm{Cl}$ was still stable after 6 months of storage in $40^{\circ} \pm$ $2^{\circ} \mathrm{C}$ with a relative humidity of $75 \pm 5 \%$. No chemical degradation was observed. In other words, according to Q1A(R2) Stability Testing Method of New Material and Drug Product guidelines, this compound could be stored and used for va rious testing until 3 years at $25^{\circ} \mathrm{C}$ with a relative humidity of $75 \pm 5 \%$, without making an extra effort to synthesize a new $3-\mathrm{CH}_{2} \mathrm{Cl}$ compound.

In summary (Fig. 6), our results showed that $3-\mathrm{CH}_{2} \mathrm{Cl}$ oral administration in intravenous LPS-treated rat model exhibited antiinflammatory activity, particularly through decreased TNF- $\alpha$ and IL$1 \beta$ pro-inflammatory cytokines, decreased white blood cell concentration, and reduced severity of lung injury. These results led to a better characterization of $3-\mathrm{CH}_{2} \mathrm{Cl}$ as a potential anti-inflammatory drug, particularly focusing on investigating the cyclooxygenases and NF- $\kappa \beta$ signaling pathways. The compound, $3-\mathrm{CH}_{2} \mathrm{Cl}$ could also stabilize the rat's body temperature during the inflammatory conditions, preventing the rats to undergo hyperthermic condition, and thus, it exhibited antipyretic activity. Additionally, $3-\mathrm{CH}_{2} \mathrm{Cl}$ was found to be stable until 3 years at $25^{\circ} \mathrm{C}$ with a relative humidity of $75 \pm 5 \%$. Taken together, this paper pointed towards the hypothetical mechanism of $3-\mathrm{CH}_{2} \mathrm{Cl}$ as a therapeutical agent in alleviating COX-related inflammatory diseases. The results could support the planning and development of $3-\mathrm{CH}_{2} \mathrm{Cl}$ in the preclinical and clinical trials.

\section{Authors contribution}

Yudy Tjahjono and Caroline designed the experiments, carried out experiments, analyzed the data, and prepared the manuscript. Efendi Anggara and Yongky Novandi carried out the experiments and analyzed the data. Srikanth Karnati, Kuncoro Foe, Hendy Wijaya, Steven, Handi Suyono, Senny Yesery Esar, Wuryanto Hadinugroho, Hevi Wihadmadyatami, Süleyman Ergün, and Ratna Megawati Widharna assisted the experiments and analyzed the data.

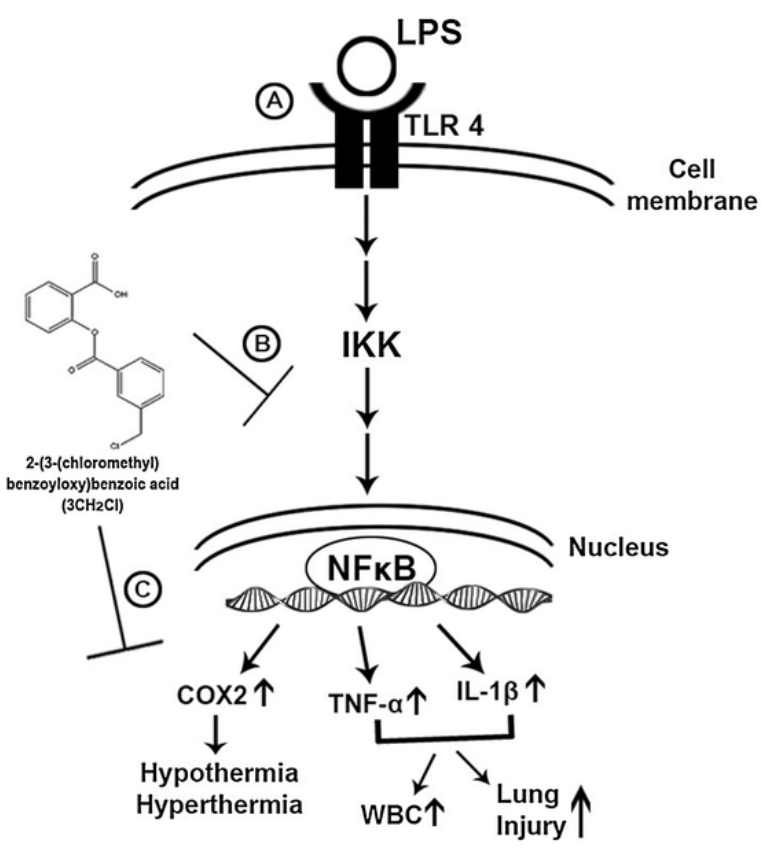

Fig. 6. Oral administration of $3-\mathrm{CH}_{2} \mathrm{Cl}$ in intravenous LPS-treated rat model exhibited anti-inflammatory activity.

(A) Classical LPS-induced inflammatory pathways at the cellular level: TLR4 signal transduction. (B) $3-\mathrm{CH}_{2} \mathrm{Cl}$ decreased the production of TNF- $\alpha$ and IL$1 \beta$ pro-inflammatory cytokines, decreased the white blood cell concentration, and reduced the severity of lung injury, presumably through IKK and $\mathrm{NF}-\kappa \beta$ signaling pathways. $3-\mathrm{CH}_{2} \mathrm{Cl}$ had an antipyretic property due to binding on its hypothetical receptor, COX-2 (C).

\section{Funding}

The work was supported by the following grants: Research and Community Service Institute of Widya Mandala Catholic University, Surabaya, Indonesia (954a/WM01.5/N/2018 to Yudy Tjahjono) and Ministry of Research, Technology and Higher Education of the Republic of Indonesia (115w/WM01.5/N/2018 to Kuncoro Foe).

\section{Acknowledgements}

We would like to thank Mr. Arnold Sulistyo Cionander, Mr. Ignasius Agyo Palmado, Ms. Siti Surdijati, Ms. Helen Kristiana Budi Agung, and Ms. Wiska Stephani Tjiali (Faculty of Pharmacy, Widya Mandala Catholic University, Surabaya) for fruitful discussion.

\section{Appendix A. Supplementary data}

Supplementary material related to this article can be found, in the online version, at doi:https://doi.org/10.1016/j.prostaglandins.2021. 106549.

\section{References}

[1] J.R. Vane, R.M. Botting, The mechanis $m$ of action of as pirin, Thromb. Res. 110 (5-6) (2003) 255-258, https://doi. org/10.1016/S0 049-3848(03)00379-7.

[2] A. Lanas, L.A. Garcia-Rodriguez, M. T. Arroyo, F. Gomollon, F. Feu, A.G. Perez, E. Zapata, G. Bastida, L. Rodrigo, S. Santolaria, M. Guell, C. M. de Argila, E. Quintero, F. Borda, J.M. Pique, Risk of upper ga stro intestinal ulcer bleeding as sociated with selective NF-k $\beta$-oxyg enase- 2 inhibitors, traditional non-as pirin non-steroidal anti-inflam ma tory drugs, as pirin and combinations, BMJ J. 55 (2006) 1731-1738, https://doi. org/10.1136/gut. 2005.080754.

[3] Y. Liu, S. Fang, X. Li, J. Feng, J. Du, L. Guo, Y. Su, J. Zhou, G. Ding, Y. Bai, S. Wang, H. Wang, Aspirin inhibits LPS-induced macrophage activation via the NF-KB pathway, Sci. Rep. 7 (1) (2017) 11549, https://doi. org/10.1038/ s41598-017-10720-4.

[4] Y. Yue, K. Xie, L. Xie, Y. Deng, Endowing poly etheretherketone with anti- 
inflammatory ability and improved osteogenic ability, J. Biomater. Sci. Polym. Ed. (2020) 1-19, https://doi. org/10.1080/09205063.2020.1815634.

[5] D.R. Patel, A. Roy, K. Pahan, PPAR $\alpha$ serves as a new receptor of as pirin for neuroprotection, J. Neuros ci. Res. 98 (4) (2019) 626-631, https://doi. or g/10. 1002/jnr. 24561.

[6] B. Cryer, K. W. Mahaffey, Gastrointestinal ulcers, role of as pirin, and clinical outcom es: pathobiology, diagnosis, and treatment, J. Multidiscip. Heal thc. 7 (2014) 137-146, https://doi. or g/10.2147/JMDH.S54324.

[7] V.E. Valkhoff, M.C. Sturkenboom, E.J. Kuipers, Risk factors for ga strointestinal bleeding as sociated with low-dose aspirin, Best Pract, Res. Clin. Gastroenterol. 26 (2) (2012) 125-140, https://doi. or g/10.1016/j. bpg. 2012.01.011.

[8] J.R. Vane, Y.S. Bakhle, R.M. Botting, Cyclooxygenases 1. and 2, Annu. Rev. Phar ma col. Toxicol. 38 (1998) 97-120, https://doi.org/10.1146/annurev. pharmtox.38.1.97.

[9] Caroline, K. Foe, S.Y. Esar, A. Soewandi, H. Wihadmadyatami, R. M. Widharna, W.D. Tama yanti, E. Kasih, Y. Tjahjono, Evaluation of analgesic and antiplatelet activity of 2-((3 (chlorom ethyl)benzoyl)oxy)benzoic acid, Prostaglandins Other Lipid Mediat. 145 (2019) 1-8, https://doi. org/10. 1016/j. prostaglandins.2019.106364.

[10] A. Waage, A. Halstensen, T. Espevik, Association between tumour necrosis factor in serum and fatal outcome in patients with meningococcal disease, Lancet 329 (8529) (1987) 355-357, https://doi. org/10.1016/S0140-6736(87) 91728-4.

[11] V. Nikoui, S. Mehrzadi, M.I. Khan, W. Aman, S. Ostadhadi, A.R. Dehpour, Licofelone, a dual cyclooxygenase/5-lipoxygenase inhibitor, revers es endotoxin-induced impaired atrial chronotropic responsiveness to cholinergic stimulation in rats, Eur. J. Phar ma col. (2020) 173569, https:// doi. org/10.1016/j. ejphar.2020.173569.

[12] X. Shen, C. Weng, Y. Wang, C. Wang, S. Feng, X. Li, H. Li, H. Jiang, H. Wang, J. Chen, Lipopoly sa ccharide-induced podocyte injury is regulated by calcineurin/NFAT and TLR4/My D88/NF- $\mathrm{kB}$ signaling pathways through angiopoietin-like protein 4, Genes Dis. (2020), https://doi.org/10.1016/j. gendis. 2020.07.005.

[13] J.Q. Wang, Y.S. Jeelall, L.L. Ferg uson, K. Horikawa, Toll-like receptors and cancer: MY D88 mutation and inflam mation, Front. Immunol. 5 (367) (2014) 1-10, https: //doi. org/10.3389/fimm u. 2014.00367.

[14] P.J. Barner, M. Karin, Transcription factor in chronic, N. Engl. J. Med. 336 (15) (1997) 1066-1071, https://doi. or g/10.1056/NEJM199704103361506.

[15] M.D. Dogan, H. Ataoglu, E.S. Akarsu, Effects of different serotypes of Escherichia coli lipopolysa ccharides on body temperature in ra ts, Life Sci. 67 (19) (2000) 2319-2329, https://doi. or g/10.1016/S0 024-3205(00)00821-3.

[16] H. Vaez, M. Naja fi, N.S. Toutounchi, J. Barar, A. Barzega, G. Alireza, Metformin al leviates lipopolysaccharide-induced acute lung injury through suppressing toll-like receptor 4 signaling, iranian journal of allergy, as thma, Immunology 15 (2016) 498-507.

[17] International Council for Harmonisation of Technical Requirements for Pharmaceuticals for Human Use, ICH Q1A (R2) Guideline, Stability Testing of New Drug Substances and Drug Products, 2021 Available online: https: // www. ema. euro pa.eu/en/documents/scientific-guideline/ich-q-1-r2-stabilitytesting-new-drug-substances-products-step-5_en.pdf (Accessed on 26 August 2020).

[18] E. Briese, Normal body temperature of rats: the setpoint controversy, Neurosci. Biobehav. Rev. 22 (3) (1998) 427-436, https://doi. org/10.1016/ S0149-7634(97)00051-1.

[19] A.B. Nair, S. Jacob, A simple practice guide for dose conversion between animals and human, J. Basic Clin. Pharm. 7 (2) (2016) 27-31, https://doi. org/10.4103/0976-0105.177703.

[20] W.T. Federer, Experimental Design, Theory and Application, Ox ford and IBH Publ. Co, New Delhi, 1967.

[21] C.F. Chian, C.H. Chiang, Y.J. Chu, C.H. Chuang, S.L. Liu, Y.H. Jheng, H. Zhang, J.H. Ryu, Apocynin attenuates lipopolysa ccharide-induced lung injury in an isolated and perfused rat lung model, Shock 38 (2) (2012) 196-202, https://doi. or g/10.1097/SH K. 0b013e31825a 1982.

[22] M. Yin, Y. Yama mo to, R. Gaynor, The anti-inflam ma tory ag ents as pirin and salicyla te inhibit the activity of IкB kinase- $\beta$, Nature 396 (1998) 77-80, https://doi. or g/10.1038/23948.

[23] P.P.S. J. Khedoe, S. Kleijn, A.M. Oeveren-Rietjdijk, J.J. Plomp, H.C. Boer, M. Pel, P.C.N. Rensen, J.F.P. Berbee, P.S. Hiemstra, Acute and chronic effects of treatment with mesenchymal stromal cells on LPS-Induced pulmonary inflam mation, emphysema and atherosclerosis development, PLoS One 12 (9) (2017) 1-21, https://doi. org/10.1371/journal. pone.0183741.

[24] S. J. Foster, L. M. McCorm ick, B.A. Ntolosi, D. Campbell, Production of TNFo by LPS-stimulated murine, rat and human blood and its pharmacological modulation, Agents Actions 38 (1993) C77-C79, https://doi.org/10.1007/ BF01991143.

[25] W.D. Tamayanti, R.M. Widharna, Ca roline, B. Soekarjo, Uji Aktivitas Analgesik Asam 2-(3-(Klorometil)Benzoiloksi)Benzoat dan Asam 2-(4(Klorometil)Benzoiloksi)Benzoat pada Tikus Wistar Jantan dengan Metode Plantar Test, Jurnal Farm asi Sa ins dan Komunitas 13 (1) (2016) 15-22, https: //doi. or g/10.24071/jpsc.131125.

[26] G. Cox, J. Gauldie, Interl eukin-6, in: D.G. Remick, J.S. Friedland (Eds.), Cy tokines in Heal th and Disease, Marcel Dekker, New York, NY, 1997, pp. 81-99.

[27] E. Tavares, F.J. Miñano, R. Maldonado, M. J. Dascombe, Endotoxin fever in granulocytopenic rats: evidence that brain cyclooxygenase-2 is more im portant than circulating prostaglandin $\mathrm{E}_{2}$, J. Leukoc. Biol. 80 (6) (2006) 1375-1387, https://doi. org/10.1189/jlb.0106064.

[28] A.Y. Rudaya, A.A. Steiner, J.R. Robbins, A.S. Drag ic, A.A. Roma novsky, Thermo regula tory responses to lipopolysa ccharide in the mouse: dependence on the dose and am bient temperature, Am. J. Physiol. Regulat. Integr . Compar. Physiol. 289 (5) (2005) R1244-R1 252, https://doi. org/10.1152/ aj pregu. 00370.2005.

[29] A. Blomqvist, D. Engblom, Neural mechanisms of inflammation induced fever, Neuros cientist 24 (4) (2018) 1-19, https://doi. or g/10.1177/ 1073858418760481 . 